\title{
"Foreign directors, indigenous directors and dividend payout structure in Nigerian deposit money banks"
}

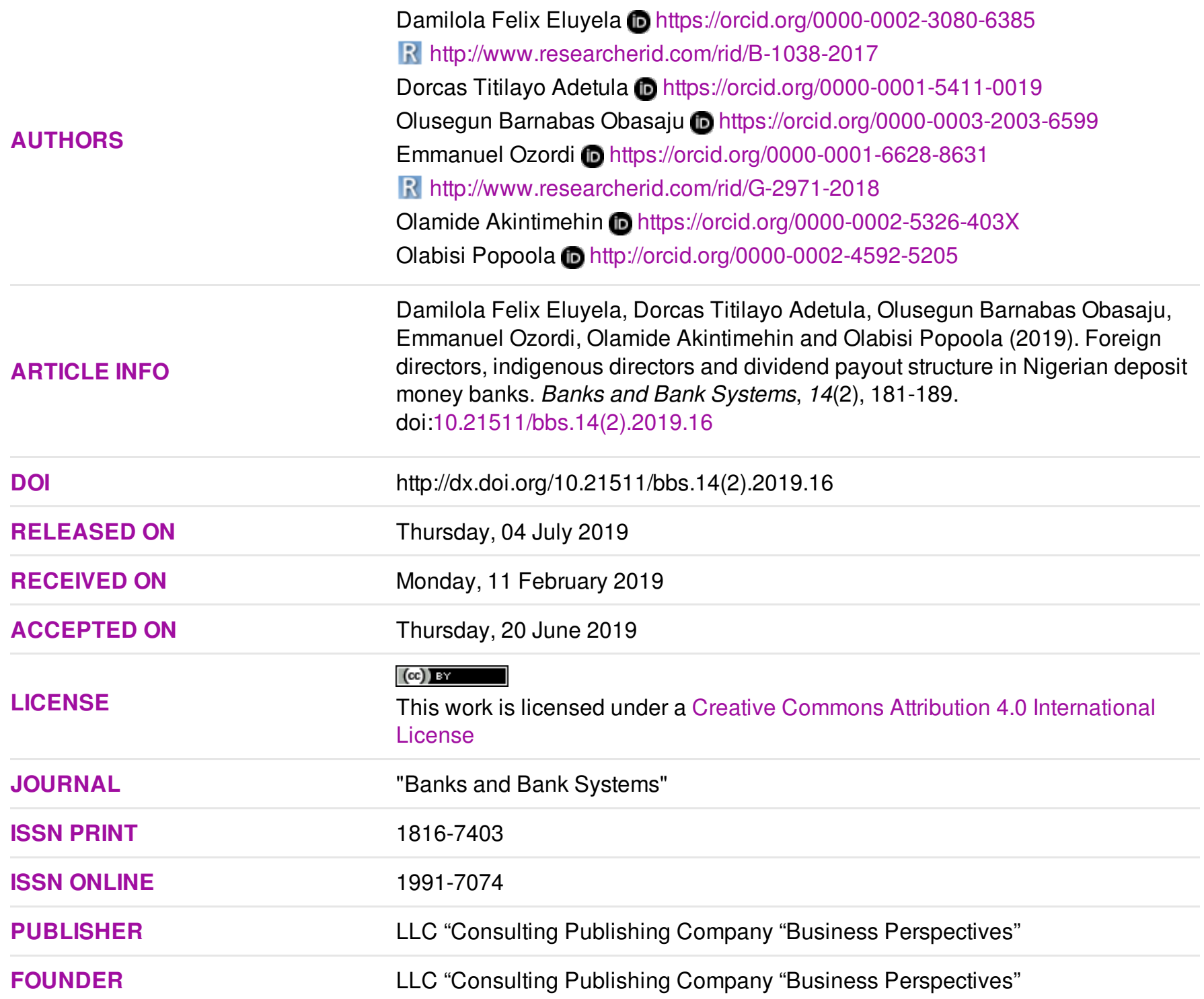

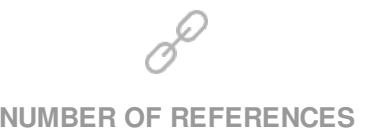

38
NUMBER OF FIGURES

0
NUMBER OF TABLES

4

(C) The author(s) 2021. This publication is an open access article. 


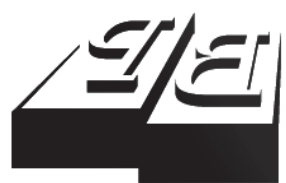

BUSINESS PERSPECTIVES

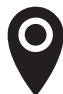

LLC "CPC "Business Perspectives" Hryhorii Skovoroda lane, 10, Sumy, 40022, Ukraine

www.businessperspectives.org

Received on: $11^{\text {th }}$ of February, 2019 Accepted on: $20^{\text {th }}$ of June, 2019

(C) Damilola Felix Eluyela, Dorcas Titilayo Adetula, Olusegun Barnabas Obasaju, Emmanuel Ozordi, Olamide Akintimehin, Olabisi Popoola, 2019

Damilola Felix Eluyela, Ph.D. Student, Lecturer, Department of Accounting and Finance, Landmark University, Nigeria.

Dorcas Titilayo Adetula, Ph.D., Associate Professor, Department of Accounting, Covenant University, Nigeria.

Olusegun Barnabas Obasaju, Ph.D., Lecturer, Department of Economics, Landmark University, Nigeria.

Emmanuel Ozordi, Ph.D. Student, Lecturer, Department of Accounting, Covenant University, Nigeria.

Olamide Akintimehin, MSc, Lecturer Department of Business Studies, Landmark University, Nigeria.

Olabisi Popoola, Ph.D. Student, Lecturer, Department of Economics, Landmark University, Nigeria.

\section{() (1)}

This is an Open Access article, distributed under the terms of the Creative Commons Attribution 4.0 International license, which permits unrestricted re-use, distribution, and reproduction in any medium, provided the original work is properly cited.
Damilola Felix Eluyela (Nigeria), Dorcas Titilayo Adetula (Nigeria), Olusegun Barnabas Obasaju (Nigeria), Emmanuel Ozordi (Nigeria), Olamide Akintimehin (Nigeria), Olabisi Popoola (Nigeria)

\section{FOREIGN DIRECTORS,} INDIGENOUS DIRECTORS AND DIVIDEND PAYOUT
STRUCTURE IN NIGERIAN
DEPOSIT MONEY BANKS

\begin{abstract}
This paper aims to examine the influence foreign and indigenous directors have on determining firms' dividend payout structure. The population for this study is the fifteen deposit money banks listed on the Nigerian Stock Exchange. Using a random sampling technique, a sample of 14 deposit money banks for the 2010 to 2017 period was taken. The total observations used for the work was 112. The study adopted a panel data methodology, which was estimated with a random-effect model. It was observed that a significant relationship exists between foreign directors and the dependent variable (dividend payout structure). The dividend payout structure by dividend per share of sampled firms was measured. This study will improve analysts and investors' understanding of dividend policy by giving them insights in identifying the main determinants of dividend policy. For policy makers, this study reinforces the fact that good corporate governance is important to develop financial markets and improve the firm value.
\end{abstract}

\section{Keywords}

corporate policy, corporate governance, dividend per share, foreign ownership, panel random effects

\section{JEL Classification G21, G35, M41}

\section{INTRODUCTION}

Corporate policy of a firm stems from three main decisions taken by its board of directors, namely dividend, investment and financing decisions. Dividend decision has become very germane in the recent financial literature (Jeon \& Ryoo, 2013; Jabbouri, 2016; Baker, Kilincarslan, \& Arsal, 2018; Ngo, Duong, Nguyen, \& Nguyen, 2018). Dividends are payments made to shareholders to compensate them for their equity stake and inherent risks of the firm. The choice of whether to pay a higher or lower level of dividends affects the growth and value of a company. For example, a higher payment of dividends can hinder further expansion and growth of a firm (Jensen, 1986). Likewise, paying a lower level of dividend will result in shareholders' dissatisfaction. This makes dividend policy a very sensitive subject in recent times. Boards of directors are saddled with the responsibility of deciding how much should be paid as a dividend to shareholders. Dividend decision is highly influenced by the ownership structure of a firm. A firm can be owned by both indigenous and foreign shareholders, these groups of people together form the board of directors. Dividends can be used as a controlling mechanism in the process of mitigating agency problems that may arise in a firm (Eluyela et al., 2018a). Likewise, large institutional shareholders may use their power as a means of expropriating 
firm resources for personal benefits at the detriment of the minor shareholders. This will in turn lead to agency conflicts (Adetula, Eluyela, Akomolafe, Ilogho, \& Adubi, 2016).

Theoretically, there have been conflicting results in the body of literature. The upper echelons theory explains that the strategic decisions of every firm are primarily influenced by background characteristics of the firm's individual top executives (Reyna, 2017). These characteristics include personalities, experiences, values, beliefs and other human factors. On the one hand, the positive school of thought believes that appointing foreign directors with different nationalities will bring different values and experience to the decision making process of the firm (Chen \& Keefe, 2018; Paniagua, Rivelles, \& Sapena, 2018). This will lead to a more timely and informed dividend decision. The other school of thought believed that the presence of foreign directors and ownership has no significant association with determination of dividend policy of such firm (Peck-Ling, Nai-Chiek, \& Chee-Seong, 2016; Duygun, Guney, \& Moin, 2018). Many of the existing literature on this subject matter focused on the developed economy where markets are well-regulated, like China, India, Russia, Latin America, United States of America and Germany (Jensen, 1986; Lee \& Moffett, 2011; Jeon, Liu, Wei, \& Xie, 2014; Benavides, Berggrun, \& Perafan, 2016; Peck-Ling, Nai-Chiek, \& Chee-Seong, 2016; Reyna, 2017; Cao, Du, \& Hansen, 2017; Duygun et al., 2018). However, there are few studies in recent times from emerging countries like Nigeria. Otekunrin et al. (2018a) is the nearest study of corporate governance and dividend policy in Nigeria. The study, however, was conducted on corporate governance variables like board size, non-executive directors and executive directors and their effect on dividend payout. Dividend payout is particularly interesting to study on Nigerian deposit money banks for at least two reasons.

The first concerns the Central Bank of Nigeria (CBN) policy on residual dividend policy issued on March 2018. The residual policy states that firms are only allowed to pay dividends after settling all outstanding obligations and management has allocated funds for reinvestment into the business. As a result of this policy, it is estimated that five out of the fifteen deposit money banks will not be able to pay a dividend in 2018 (Otekunrin et al., 2018b). Secondly, there have been issues of non-payment of dividends among some deposit money banks for the past five years. However, what have been the roles of foreign directors on the dividend payout structures? This question is akin to seeking to investigate if the positive school of thought that prioritizes the appointment of foreign directors holds sway. Contrarily, have the indigenous directors been more valuable to deposit money banks in Nigeria? These questions have been ignored by Otekunrin et al. (2018a), but the answers are important for fashioning appropriate policies. In a nutshell, this study is poised to filling the identified lacuna in the literature by proffering answers to these questions.

In simple parlance, this work focuses on the influence foreign and indigenous directors have on determining firms' dividend payout structure, using a sample of deposit money banks in the listed Nigerian context from 2010 to 2017. To achieve the objective, this paper is structured as follows: the next section presents the literature review with the hypothesis being outlined, followed by the methods and materials used in the study. Then, the results and discussion of findings are provided. The paper wraps up with the conclusion, outlines suitable recommendations and provides suggestions for future research in this area.

\section{LITERATURE REVIEW}

\subsection{General idea}

The article reviewed the various related literature on the nexus between each of the independent variables - foreign directors, indigenous direc- tors, non-executive directors, foreign ownership, and the dependent variable - dividend payout structure. At the end of every operationalized variable, the null hypothesis was formulated that was verified in the later section of this study. This study is anchored on the upper echelon theory (Felicio, Couto, \& Caiado, 2014; Clarke, Chandra, 
\& Machado, 2016). This theory explains how strategic decisions of every firm are influenced by personal characteristics (culture, experience and skills) of the firm's top executives. The justification for this theory is that the decision whether to pay a high dividend or not depends on the personal characteristics of the board members who are made up of different cultural background, belief and value system, experience and qualification. However, the results that emanate from the empirical analysis can suggest the applicability of theories such as the positive theory and the other school of thought, which contradicts the positive theory.

\subsection{Foreign directors and dividend payout structure}

The issue of the firm having a diverse board has been a consistent debate in recent finance literature (Khan, Hassan, \& Marimuthu, 2017; Nadeem, Zaman, \& Saleem, 2017; Ozordi, Uwuigbe, Teddy, Tolulope, \& Eyitomi, 2018). Diversity can be in age, gender, experience and nationalities. Empirical evidence from previous studies on the presence of foreign directors and determination of dividend payout structure has shown mixed results. PeckLing et al. (2016) investigated the effect of foreign ownership and foreign directors on the profitability of Malaysian listed companies between 1999 and 2010. Using a sample of 348 Malaysian firms, the fixed effect panel regression shows that foreign equity ownership, the appointment of foreign chairman and foreign chief executive directors did not have a significant relationship with return on equity of the sampled firms. However, foreign directors on board have a significant effect on return on equity. Subsequently, in the Mexican context, Reyna (2017) found a positive relationship amidst the aforementioned constructs. However, Jeon and Ryoo (2013) and Benavides et al. (2016) found an insignificant association between foreign directors and dividend payout structure in India and Korea respectively. Against this mixed result in the body of existing knowledge, the first hypothesis is stated as:

\section{H1: There is no significant relationship between foreign directors and the determination of dividend payout structure of listed Nigerian deposit money banks.}

\subsection{Indigenous directors and dividend payout structure}

The Nigerian indigenization policy of 1977 required that at least $60 \%$ of every company board of directors must be a nationality of Nigeria. Also, the act detailed that not less than 51\% (fifty-one) equity shares owned of every company should be held by Nigerian investors. This policy was formulated to protect and attract local content in all Nigerian firms. In this light, $\mathrm{He}$, Ng, Zaiats, and Zhang (2017) believed that a board that has a high number of domestic directors pay more dividends than those that do not. This is in contrast with the work of SierraGarcia, Zorio-Grima, and Garcia-Benau (2015) who opined that no significant relationship exists between domestic directors and dividend payout structure of firms. Against this mixed evidence found in empirical literature, this study hypothesized that:

H2: Indigenous directors do not have any significant impact on the determination of dividend payout structure of listed Nigerian deposit money banks.

\subsection{Non-executive directors and dividend payout structure}

The mixture of independent non-executive directors and executive directors on board is also an important variable to consider. The major difference between these two important variables is that the former is not involved in the day to day running of the business enterprise (Adetula, 2009; Ayadi, Ojo, Ayadi, \& Adetula, 2015). Hwang, Kim, Park, and Park (2013) argued that a higher representation of non-executive directors on board reduces agency conflicts and gives room for payment of higher dividends. However, Chen and Keefe (2018) opined that there is no significant relationship between non-executive directors and dividend payout structure of sampled deposit money banks in Nigeria. This conflicting evidence in empirical literature leads us to the following statement:

H3: Non-executive directors do not significantly influence the dividend payout structure of listed Nigerian deposit money banks. 


\subsection{Foreign ownership and dividend payout structure}

Foreign ownership is the percentage of company shareholdings owned by foreign investors (Uwuigbe, Eluyela, Uwuigbe, Obakpro, \& Falola, 2018). Baba (2009) and Cao et al. (2017), using a choice-to-change and generalized methods of moments $(G M M)$ model respectively, opined that a higher level of foreign ownership is associated with a significantly higher probability of dividend payouts and vice versa. This is evident in the notion that firms that increase their dividend payout will attract a large proportion of foreign investors. This is because foreign investors are rational individuals and select firms that pay higher dividends. Duygun et al. (2018) noted that there is no relationship between foreign investors and the payment of dividends in firms. Against this inconclusive result in literature, the fourth hypothesis is stated as follows:

H4: There is no significant relationship between foreign ownership and determination of dividend payout of listed Nigerian deposit moneybanks.

\section{MATERIALS AND METHODS}

The population for this work is the fifteen deposit money banks listed on the Nigerian Stock Exchange. A random sampling technique was used to select fourteen sampled banks. One of these banks was not considered as sample for this study because of the recent acquisition and change of name by the Central Bank of Nigeria $(C B N)$. The information about independent variables (foreign directors, indigenous directors, non-executive directors, foreign ownership) and the dependent variable (dividend payout structure) was sourced from annual reports of sampled banks that were published on the Nigerian Stock Exchange website. The time frame for this study is 2010-2017 representing a period of eight years. With a cross-section of 14 and time series of eight, the total observations amount to 112 . The time series and cross-section dimensions here are similar to those of Eluyela et al. (2018b), Popoola, Asalaye, and Eluyela (2018). Some control variables in this work were added to ensure the robustness of the model specification (see Asaleye, Lawal, Popoola, Alege, \& Oyetade, 2019). These variables are board size, firm age and firm size. As a precursor to the empirical results, descriptive statistics is presented to provide insight on the minimum, maximum and mean value, inter alia, of each variable (Oladipo, Iyoha, Fakile, Asaleye, \& Eluyela, 2019). Table 1 below shows the measurement of variables adopted in this work. Dividend per share is used as a measure of the dividend payout structure of sampled deposit money banks in Nigeria. The independent variables are operationalized as contained in Table 1.

Table 1. Summary of variables

Source: Author's compilation (2018).

\begin{tabular}{|c|c|c|c|}
\hline $\begin{array}{l}\text { Variable } \\
\text { acronym }\end{array}$ & $\begin{array}{l}\text { Variable } \\
\text { name }\end{array}$ & Variable type & Measurement \\
\hline DPS & $\begin{array}{l}\text { Dividend per } \\
\text { share }\end{array}$ & Dependent & $\begin{array}{l}\text { The total dividend } \\
\text { paid/number of } \\
\text { shares issued }\end{array}$ \\
\hline FOD & $\begin{array}{l}\text { Foreign } \\
\text { directors }\end{array}$ & Independent & $\begin{array}{l}\text { Number of foreign } \\
\text { directors/total } \\
\text { number of board } \\
\text { members }\end{array}$ \\
\hline IND & $\begin{array}{l}\text { Indigenous } \\
\text { directors }\end{array}$ & Independent & $\begin{array}{c}\text { Number of indigenous } \\
\text { directors/total } \\
\text { number of board } \\
\text { members }\end{array}$ \\
\hline NED & $\begin{array}{l}\text { Non- } \\
\text { executive } \\
\text { directors }\end{array}$ & Independent & $\begin{array}{c}\text { Number of non- } \\
\text { executive directors/ } \\
\text { total number of board } \\
\text { members }\end{array}$ \\
\hline FOW & $\begin{array}{l}\text { Foreign } \\
\text { ownership }\end{array}$ & Independent & $\begin{array}{c}\text { Shares owned by } \\
\text { foreign directors/ } \\
\text { total number of } \\
\text { shares in the firm }\end{array}$ \\
\hline FAGE & Firm age & Control & $\begin{array}{c}\text { Number of years } \\
\text { the firm has been in } \\
\text { existence }\end{array}$ \\
\hline FSIZE & Firm size & Control & $\begin{array}{c}\text { Log of total assets of } \\
\text { the firm }\end{array}$ \\
\hline BSIZE & Board size & Control & $\begin{array}{c}\text { Number of board } \\
\text { members }\end{array}$ \\
\hline
\end{tabular}

\section{EMPIRICAL MODEL AND ESTIMATION STRATEGY}

\subsection{Empirical model}

Following Duygun et al. (2018), dividend payout structure is first expressed as a function of foreign and indigenous directors as contained in equation (1): 
Table 2. Summary statistic

Source: Authors' using STATA software.

\begin{tabular}{|c|c|c|c|c|c|}
\hline Variable & Observation & Mean & Std. Dev. & Minimum & Maximum \\
\hline DPS & 92 & 0.590 & 0.592 & 0 & 2.45 \\
\hline FOD & 104 & 0.141 & 0.130 & 0 & 0.538 \\
\hline IND & 112 & 0.868 & 0.131 & 0.462 & 1 \\
\hline BSIZE & 112 & 14.161 & 2.915 & 7 & 25 \\
\hline NED & 112 & 0.590 & 0.116 & 0 & 0.833 \\
\hline FSIZE & 112 & 11.646 & 0.756 & 9.010 & 12.684 \\
\hline FAGE & 112 & 39.786 & 27.990 & 4 & 123 \\
\hline
\end{tabular}

$$
D P S=f(F O D, I N D)
$$

Garnering crucial insights from the literature, this study augments equation (1) with other important independent variables. This leads to equation (2), which is the model to be estimated.

$$
\begin{aligned}
& D P S_{i t}=\beta_{0}+\beta_{1} F O D_{i t}+\beta_{2} I N D_{i t}+ \\
& +\beta_{3} N E D_{i t}+\beta_{4} F A G E_{i t}+\beta_{5} F S I Z E_{i t}+ \\
& +\beta_{6} B S I Z E_{i t}+\delta_{i}+\varphi_{t}+\varepsilon_{i t}
\end{aligned}
$$

where DPS is a dividend per share; FOD is foreign directors; IND is indigenous directors; $N E D$ is non-executive directors; $F A G$ is a firm age; FSIZE is a firm size and BSIZE is a board size. $\beta_{i}$ are coefficients; $\delta_{i}$ and $\varphi_{t}$ are time-varying and entity (firm) fixed effects, respectively. They are dummy variables assuming the values 1 (when dealing with a particular year or deposit money bank) and 0 (otherwise) (see Obasaju, Olayiwola, Okodua, \& Obasaju (2018) for an alternative use of the fixed effect dummies). The reason for the inclusion of these fixed effects is stated under the estimation strategy (Asaleye, Adama, \& Ogunjobi, 2018). The subscripts $i$ and $t$ are characteristic of panel data and respectively indicate entity/ cross-section/firm specific features and a particular time; $\varepsilon_{i t}$ is the idiosyncratic error term which accounts for other omitted independent variables.

\subsection{Estimation strategy}

To analyze the relationship between the independent variables of interest and the dependent variable (dividend payout), first, the Hausman test is carried out to choose between the fixed or random effects techniques. A significant estimate supports the fixed effects technique, otherwise, a random effect is appro- priate. To allow for heteroscedasticity and serial correlation ${ }^{1}$, the cluster-robust Huber/White standard errors are used. This makes it possible to obtain reliable standard error estimates. With the cluster-robust standard errors, each individual, in the present case, each firm, can be treated as a cluster. And as shown in equation (2), both time and cross-sectional fixed effects are included (dummy variables). This is in order to account for variables which vary with time and across entities (firms), which are not included in the model but have influence on the dependent variable $^{2}$. To investigate the robustness of the empirical estimates, the least square dummy variable (LSDV) technique is employed. The choice of LSDV follows from the excess of the cross-section dimension (14 firms) over the time series dimension (eight years) (see Greene, 2008; Ashley, 2012; and Asaleye, Popoola, Lawal, Ogundipe \& Ezenwoke, 2018).

\section{RESULTS AND DISCUSSION}

The summary statistic of variables is first presented in Table 2.

From Table 2, the dividend per share and foreign ownership do not have data for a few years. These two variables, including the non-executive directors (NED), also have minimum values of zero. Next, the result of the Hausman test is presented. This is followed by the empirical results.

Table 3. The Hausman test for the choice between fixed or random effects

Source: Authors' using STATA software.

\begin{tabular}{c|c}
\hline Chi-square & 0.00 \\
\hline Prob. (Chi-square) & 1.000 \\
\hline
\end{tabular}

1 Any collinearity is also dealt with as the software automatically drops any variables that can induce collinearity/multicollinearity into the model.

2 The inclusion of the fixed effects can also serve to mitigate the possibilities of reverse causations. 
With the insignificant value of the chi-square as shown by its probability (1.000), it may be concluded that the random effect technique is appropriate (see Table 3). Table 3 reports the results using the random effect technique while also including the LSDV estimates to check the sensitivity of the results to the technique used.

Table 4. Empirical results

Source: Authors' using STATA software.

\begin{tabular}{|c|c|c|}
\hline Variable & Random effects & LSDV \\
\hline FOD & $\begin{array}{c}2.330^{* *} \\
(1.026) \\
{[2.27]}\end{array}$ & $\begin{array}{c}2.330^{* *} \\
(0.957) \\
{[2.43]}\end{array}$ \\
\hline IND & $\begin{array}{c}0.709 \\
(0.821) \\
{[0.86]}\end{array}$ & $\begin{array}{c}0.709 \\
(0.878) \\
{[0.81]}\end{array}$ \\
\hline BSIZE & $\begin{array}{c}-0.044 \\
(0.037) \\
{[-1.20]}\end{array}$ & $\begin{array}{c}-0.044^{* *} \\
(0.020) \\
{[-2.17]}\end{array}$ \\
\hline NED & $\begin{array}{c}-0.980^{* *} \\
(0.435) \\
{[-2.25]}\end{array}$ & $\begin{array}{r}-0.980^{*} \\
(0.503) \\
{[-1.94]}\end{array}$ \\
\hline FSIZE & $\begin{array}{c}0.135^{*} \\
(0.082) \\
{[1.65]}\end{array}$ & $\begin{array}{c}0.135^{*} \\
(0.073) \\
{[1.84]}\end{array}$ \\
\hline FAGE & $\begin{array}{c}0.058^{* * *} \\
(0.008) \\
{[7.17]}\end{array}$ & $\begin{array}{c}0.021 \\
(0.026) \\
{[0.81]}\end{array}$ \\
\hline $\begin{array}{l}\text { R-squared } \\
\text { Adjusted R-squared } \\
\text { F-stat. }\{\text { Wald Chi-square }\} \\
\text { Prob. of F\{Prob. of Wald } \\
\text { Chi-square }\}\end{array}$ & $\begin{array}{c}0.824 \\
- \\
\{34.99\} \\
\{0.000\}\end{array}$ & $\begin{array}{c}0.824 \\
0.757 \\
3.32 \\
0.001\end{array}$ \\
\hline Time fixed effects & Yes & Yes \\
\hline Firm fixed effects & Yes & Yes \\
\hline
\end{tabular}

Notes: The R-squared for the Random Effects estimates indicate the overall $\mathrm{R}$-squared. $* * *, * *$ and $*$ denote significance at the $1 \%, 5 \%$ and $10 \%$ levels, respectively. Values in ( ) and [] denote standard errors and $t$ (or z) statistic, respectively. In the lower segment of Table 3 , values in \{\} denote the Wald Chi-square or its probability.

The overall tests of the significance of the model and the goodness of fit indicate that the model, irrespective of the technique used, is significant. This is shown by the high significance of Wald Chi-Square - even at one percent level (in the case of random effects) and the F-statistics (in the case of LSDV). The values of the R-squared and the Adjusted R-squared, which are respectively 0.824 and 0.757 , indicate that the model has a good fit (see Table 3 ). They respectively suggest that the independent variables explain over 82 and 76 percent variation in the dependent variable - dividend payout structure.
The presence of foreign directors $(F O D)$ in the Nigerian deposit banks is clearly a plus, as this variable is positive and statistically significant at the five percent level as estimated by both techniques. Thus, the study rejects the null hypothesis that there is no significant relationship between foreign directors and dividend payout structure by the Nigerian deposit banks. This points to the fact that the presence of more foreign directors positively and significantly boosts the abilities of the Nigerian deposit banks to pay out dividends to their customers. This may result from the experience and knowledge brought on board by foreign directors. This result correlates with Peck-Ling et al. (2016) and Reyna (2017) who conclude that the presence of foreign directors on board has a positive and significant influence on the determining dividend payout. However, Jeon and Ryoo (2013) and Benavides et al. (2016) opined that the presence of foreign expatriate on board has a positive insignificant influence on dividend payouts.

For the indigenous directors (IND), this variable has a positive coefficient, which implies that the presence of indigenous directors increases dividend payouts. But in terms of the degree of influence, this variable is not statistically significant. Therefore, the null hypothesis of no significant relationship between this variable and the dependent variable cannot be rejected. The import of this is that although the presence of indigenous directors improves dividend payouts in the Nigerian deposit banking sector, the extent to which their presence boosts dividend payouts is not sufficient; the two techniques agree with this conclusion. Hence, when the two sets of directors are placed side-byside, the influence of foreign directors, in terms of their value-generating impact (which in this context is the ability to payout dividends), is stronger than that of indigenous directors. One of the implications of this empirical outcome for policy is that, if Nigerian directors seek to meaningfully improve the dividend payout structure of their banks when they are at the helm of affairs, the need to understudy the practices of their foreign counterparts is exigent. From a similar perspective, this finding may be taken to mean a wakeup call for indigenous directors to up their knowledge horizons in areas that can aid value addition in respect of the payout dividend structure. This finding corroborates Sierra-Garcia, Zorio-Grima, 
and Garcia-Benau (2015) who believe that the presence of indigenous directors on top level management has a positive insignificant impact on the determination of dividend payout structure but is in contrast with $\mathrm{He}, \mathrm{Ng}$, Zaiats, and Zhang (2017).

The third independent variable of interest is the non-executive directors (NED). The two techniques conclude that the presence of non-executive directors at the helm of affairs does more harm than good. In fact, their presence significantly reduces the ability of the deposit banks in Nigeria to pay out dividends to the shareholders. The null hypothesis that there is no significant relationship between these variables is hereby rejected. The negative and significant impact suggests the need for deposit banks to have a rethink when trying to bring non-executive directors on board when it comes to the day-to-day running of their organization. This finding resonates with Hwang, Kim, Parkand, and Park (2013) who attest to the significant relationship that exists amidst similar variable constructs. However, it contradicts the work of Chen and Keefe (2018) who opined that inclusion of non-executive directors on board has an insignificant impact on dividend payout determination.

Considering the control variables, the board size (BSIZE), that is the number of members on board, reduces dividend payouts of deposit money banks in Nigeria; the two techniques agree in this respect. But in terms of significance, the random effects show that although having more members on board reduces the dividend payout, this reduction is not to a significant degree. The LSDV estimate, however, shows that the reduction is to a significant degree. Considering the disparity in the estimates of the two techniques in the area of statistical significance, it may be safely concluded that increases in board size shrinks dividend per share given by the Nigerian deposit banks to their customers. In essence, empirical evidences from this study suggest the need to discourage having large numbers of members on the board of Nigerian deposit banks. The reason for this negative implication of board size for dividend payout may not be unconnected to that part of the total dividend carted away by the large size of board members. This is especially likely in the event that some of the board members have high propensities of engaging in 'sharp' practices to the detriment of dividend per shareholder. But a 'sharp' practice is just a conjecture as this is not factored into the present model.

Firm size (FSIZE) is another control variable included in the model. The two techniques conclude, as expected, that the larger the total assets of a deposit bank, the more their ability to pay out dividends. This variable is, however, weakly significant as both techniques show that it is only significant at the 10 percent level. At any rate, the positive and significant nexus between firm size and dividend payout reinforces the need for the directors of the Nigerian deposit banks to find more innovative means (legal means) to increase their total assets ${ }^{3}$.

Finally, the age of a firm (FAGE) is another variable included to control for the age of a deposit money bank. The two techniques depict that this variable positively influences the ability of deposit banks to give out dividends. The random effects show that firm age is both a positive and significant driver of dividend payout by deposit banks in Nigeria, while the LSDV's estimate shows that it is a positive but not significant driver. Yet, what is clear is that whether or not it is to a significant degree, firms are able to give out more dividends to their customers as they increase in age.

\section{CONCLUSION}

The article analyzed one of the most fundamental business decisions that directly influence the spirit of any investor. Thus, the focus was on assessing the influence foreign and indigenous directors have on determining a firm dividend payout structure, using a sample of deposit money banks in the list-

3 The fact that the firm size is also dependent on some factors, which may be used to increase its value, this variable may exhibit an endogenous nature. Yet, as stated under the estimation strategy, the inclusion of the time and entity/firm fixed effects are counted on to mitigate the possibilities of reverse causations. Foreign ownership (as a variable) was excluded for a similar reason. The initial inclusion of this variable (foreign ownership) 'corrupted' the results, that is, led to implausible estimates. Thus, this variable was dropped from the modelling exercise. 
ed Nigerian context, taking a reference from 2010 to 2017. The variables found to be significant determinants of dividend payout structure of the Nigerian deposit money banks include foreign directors, non-executive directors, firm size and firm age. But the presence of non-executive directors was found to exert a negative impact on the dividend payout. The result of this study has practical implications for investors, analysts and regulators. This study will improve analysts and investors' understanding of dividend policy by giving them insights in identifying the main determinants of dividend policy. For policy makers, this study reinforces the understanding that good corporate governance is important in developing financial markets and improving firm value. The major limitation of this study is in relation to the sampled population considered. The study only examined the influence of foreign directors and indigenous directors on determination of dividend payout structure of deposit money banks in Nigeria. Further studies can look at other sectors listed on the Nigerian Stock Exchange.

\section{REFERENCES}

1. Adetula, D. T. (2009). Value relevance of accounting information in emerging stock market: the case of Nigeria. A paper presented at $10^{\text {th }}$ Annual International Conference of Academy of African Business and Development (IAADB), 9-14.

2. Adetula, D. T., Eluyela, D. F., Akomolafe, J. A., Ilogho, S. O., \& Adubi, A. O. (2016). Cost management and performance of manufacturing companies: A study of listed firms in Nigeria. Proceedings of the 28th International Business Information Management Association Conference - Vision 2020: Innovation Management, Development Sustainability, and Competitive Economic Growth.

3. Asaleye, A. J., Adama, J. I., \& Ogunjobi, J. O. (2018). Financial sector and manufacturing sector performance: evidence from Nigeria. Investment Management and Financial Innovations, 15(3), 35-48. http://dx.doi.org/10.21511/ imfi.15(3).2018.03

4. Asaleye, A. J., Lawal, A. I., Popoola, O., Alege, P. O., \& Oyetade, O. O. (2019). Financial Integration, Employment and Wages Nexus: Evidence from Nigeria. Montenegrin Journal of Economics, 15(1), 141-154. Retrieved from http://repec.mnje.com/mje/2019/ v15-n01/mje_2019_v15-n01-a21. pdf

5. Asaleye, A. J., Popoola, O., Lawal, A. I., Ogundipe, A., \& Ezenwoke, O. (2018). The credit channels of monetary policy transmission: implications on output and employment in Nigeria. Banks and Bank Systems, 13(4), 103118. http://dx.doi.org/10.21511/ bbs.13(4).2018.10

6. Ashley, R. A. (2012). Fundamentals of applied econometrics ( $1^{\text {st }} \mathrm{ed}$.). USA: Thomson Digital.

7. Ayadi, O. F., Ojo, A. T., Ayadi, M. F., \& Adetula, D. T. (2015). Gender diversity in the governance of the Nigerian securities market. Corporate Governance (Bingley), 15(5), 734-746. https://doi. org/10.1108/CG-01-2015-0007

8. Baba, N. (2009). Increased presence of foreign directors and dividend poilicy of Japanese firms. Pacifin-Basin Financer Journal, 17, 163-174.

9. Baker, K. H., Kilincarslan, E., \& Arsal, A. H. (2018). Dividend policy in Turkey: Survey evidence from Borsa Istanbul firms. Global Finance Journal, 35, 43-57. https:// doi.org/10.1016/j.gf.2017.04.002

10. Benavides, J., Berggrun, L., \& Perafan, H. (2016). Dividend payout policies: Evidence from Latin America. Finance Research Letters, 17, 197-210. https://doi. org/10.1016/j.frl.2016.03.012

11. Cao, L., Du, Y., \& Hansen, J. Ø. (2017). Foreign institutional investors and dividend policy: Evidence from China. International Business Review, 26(5), 816-827. https://doi. org/10.1016/j.ibusrev.2017.02.001
12. Chen, Z., \& Keefe, M. O. C. (2018). Board of director compensation in China: To pay or not to pay? How much to pay? Emerging Markets Review, 37, 66-82. https://doi. org/10.1016/j.ememar.2018.05.003

13. Clarke, R., Chandra, R., \& Machado, M. (2016). SMEs and social capital: exploring the Brazilian context. European Business Review, 28(1), 2-20. https://doi.org/10.1108/EBR-032013-0065

14. Duygun, M., Guney, Y., \& Moin, A. (2018). Dividend policy of Indonesian listed firms: The role of families and the state. Economic Modelling, 75, 1-19. https://doi.org/10.1016/j.econmod.2018.07.007

15. Eluyela, D. F., Akintimehin, O. O., Okere, W., Ozordi, E., Osuma, G. O., Ilogho, S. O., \& Oladipo, O. A. (2018a). Datasets for board meeting frequency and financial performance of Nigerian deposit money banks. Data in Brief, 19, 1852-1855. https://doi. org/10.1016/j.dib.2018.06.044

16. Eluyela, D. F., Akintimehin, O. O., Okere, W., Ozordi, E., Osuma, G. O., Ilogho, S. O., \& Oladipo, O. A. (2018b). Board meeting frequency and firm performance: examining the nexus in Nigerian deposit money banks. Heliyon, 4(10), 1-14. https://doi.org/10.1016/j.heliyon.2018.e00850

17. Felicio, J. A., Couto, E., \& Caiado, J. (2014). Human capital, social capital and organizational 
performance. Management Decision, 52(2), 350-364. https:// doi.org/10.1108/MD-04-20130260

18. Greene, W. H. (2008). Econometric Analysis ( $6^{\text {th }}$ ed.). Upper Saddle River, NJ: Prentice Hall.

19. He, W., Ng, L., Zaiats, N., \& Zhang, B. (2017). Dividend policy and earnings management across countries. Journal of Corporate Finance, 42, 267-286. https://doi. org/10.1016/j.jcorpfin.2016.11.014

20. Hwang, L. S., Kim, H., Park, K., \& Park, R. S. (2013). Corporate governance and payout policy: Evidence from Korean business groups. Pacific Basin Finance Journal, 24, 179-198. https://doi. org/10.1016/j.pacfin.2013.04.006

21. Jabbouri, I. (2016). Determinants of corporate dividend policy in emerging markets: Evidence from MENA stock markets. Research in International Business and Finance, 37, 283-298. https://doi. org/10.1016/j.ribaf.2016.01.018

22. Jeon, J. Q., \& Ryoo, J. (2013). How do foreign investors affect corporate policy?: Evidence from Korea. International Review of Economics and Finance, 25, 52-65. https://doi.org/10.1016/j. iref.2012.05.001

23. Jeon, J. Q., Lee, C., \& Moffett, C. M. (2011). Effects of foreign ownership on payout policy: Evidence from the Korean market. Journal of Financial Markets, 14(2), 344-375. https://doi.org/10.1016/j. finmar.2010.08.001

24. Khan, H., Hassan, R., \& Marimuthu, M. (2017). Diversity on Corporate Boards and Firm Performance: An Empirical Evidence from Malaysia. American Journal of Social Sciences and Humanities, 2(1), 1-8. Retrieved from https://ideas.repec.org/a/onl/ ajossh/2017p1-8.html

25. Liu, Y., Wei, Z., \& Xie, F. (2014). Do women directors improve firm performance in China? Journal of Corporate Finance, 28, 169-184. https://doi.org/10.1016/j.jcorpfin.2013.11.016

26. Nadeem, M., Zaman, R., \& Saleem, I. (2017). Boardroom gender diversity and corporate sustainability practices: Evidence from Australian Securities Exchange listed firms. Journal of Cleaner Production, 149, 874885. https://doi.org/10.1016/j. jclepro.2017.02.141

27. Ngo, A., Duong, H., Nguyen, T., \& Nguyen, L. (2018). The effects of ownership structure on dividend policy: Evidence from seasoned equity offerings (SEOs). Global Finance Journal (Available online June 15, 2018, No. 100440). https:// doi.org/10.1016/j.gf.2018.06.002

28. Obasaju, B. O., Olayiwola, W. K., Okodua, H., \& Obasaju, U. Z. (2018). Does intermediate tariff bode well for trade integration in ECOWAS? Journal of International Studies, 11(4), 201-214. https://doi. org/10.14254/2071-8330.2018/11$4 / 14$

29. Oladipo, O. A., Iyoha, O. F., Fakile, A. S., Asaleye, A. J., \& Eluyela, D. F. (2019). Do government taxes have implications on manufacturing sector output? Evidence from Nigeria. Journal of Management Information and Decision Sciences, 22(3), 181-190.

30. Otekunrin, A. O., Nwanji, T. I., Hermans, R. E., Ajayi, S. A., Dayo, F., Falaye, A. J., \& Eluyela, D. F. (2018a). Dividend policy and corporate governance regulation and practice in Nigerian banks. Journal of Management Information and Decision Sciences, 10(2), 18-59. Retrieved from http:// eprints.lmu.edu.ng/1638/1/DIVIDEND\%20POLICY\%20AND\%20 CORPORATE\%20GOVERNANCE.pdf

31. Otekunrin, O. A., Nwanji, T. I., Egbide, B., Fakile, S. A., Ajayi, S. A., Falaye, A. J., \& Eluyela, D. F. (2018b). Profitability Ratios and Market Price of Share of Selected Firms in Quoted Nigeria Agriculture and Agro-Allied Firms: After adoption of International Financial Reporting Standard. In Proceedings of the $32 \mathrm{rd}$ International Business Information Management Association Conference, Seville, Spain.

32. Ozordi, E., Uwuigbe, U., Teddy, O., Tolulope, I., \& Eyitomi, G. A.
(2018). Corporate diversity and corporate social environmental disclosure of listed manufacturing companies in Nigeria. Problems and Perspectives in Management, 16(3), 229-244. https://doi. org/10.21511/ppm.16(3).2018.19

33. Paniagua, J., Rivelles, R., \& Sapena, J. (2018). Corporate governance and financial performance: The role of ownership and board structure. Journal of Business Research, 89(February), 229234. https://doi.org/10.1016/j. jbusres.2018.01.060

34. Peck-Ling, T., Nai-Chiek, A., \& Chee-Seong, L. (2016). Foreign Ownership, Foreign Directors and the Profitability of Malaysian Listed Companies. Procedia Social and Behavioral Sciences, 219, 580-588. https://doi.org/10.1016/j. sbspro.2016.05.037

35. Popoola, O., Asalaye, A. J., \& Eluyela., D. F. (2018). Domestic revenue mobilization and Agricultural productivity: evidence from Nigeria. Journal of Advanced Research in Law and Economics, 9(4), 1439-1450. https://doi. org/10.14505//jarle.v9.4(34).31

36. Reyna, J. M. S. M. (2017). Ownership structure and its effect on dividend policy in the Mexican context. Contaduria y Administracion, 62(4), 11991213. https://doi.org/10.1016/j. cya.2015.12.006

37. Sierra-Garcia, L., Zorio-Grima, A., \& Garcia-Benau, M. A. (2015). Stakeholder Engagement, Corporate Social Responsibility and Integrated Reporting: An Exploratory Study. Corporate Social Responsibility and Environmental Management, 22(5), 286-304. https://doi.org/10.1002/ csr. 1345

38. Uwuigbe, U., Eluyela, D. F., Uwuigbe, O. R., Obakpro, T., \& Falola, I. (2018). Corporate governance and quality of financial statements: a study of listed Nigerian banks. Banks and Bank Systems, 13(3), 12-23. https://doi. org/10.21511/bbs.13(3).2018.02 